\title{
The Moderating Role of Need for Personal Interaction in the Relationship between E-Quality, E-Satisfaction and Commitment "Case of Moroccan E-Banking Users"
}

\author{
Chakib Hamadi
}

ENCG-University of Marrakesh, Morocco

\begin{abstract}
This article demonstrates that the need for personal interaction has no moderating effect on the relationship between e-quality and e-satisfaction, either in the relationship between esatisfaction and commitment. The results reveal that a high or low need for personal interaction does not modify these relationships for Moroccan e-banking users.
\end{abstract}

Keywords: e-Quality, e-satisfaction, commitment, need for personal interaction.

\section{Introduction}

The change of banking environment through the use of Internet technology has influenced the interaction with banking services. From services with high levels of personnel interaction, where the face to face need has a strong influence on credibility, we went to services where interaction is low or absent. However, direct council and exchange between individuals remain indispensable for many customers less open to technology. Indeed, the personal interaction does not disappear in favour of a relationship mediated by the Internet. Moreover, some authors as Zhu and al. (2002) found that consumers who need personal attention evaluate above traditional dimensions of service quality. In addition, the need for personal attention accentuates the preference for traditional services. The preference for traditional services has a direct effect on the perception of the dimensions of perceived quality. Some people perceive that the use of high technology in meeting service dehumanizes interaction. They may eventually change companies if they lose the human interaction with their provider (Gerson, 1998).
In view of the foregoing, we postulate that consumers with a high need for interaction with personal service would express much higher expectations about the e-quality than those with low need. We consider that the need for interaction with service staff moderates the relationship between perceived e-quality and e-satisfaction and the relationship between e-satisfaction and commitment.

The aim of this paper is to test the moderating role of need for personal interaction in the above-mentioned relations. It is organized as follows: initially, the conceptual framework is exposed, then the methodology will be presented and finally the results and the contributions of the research will be shown and discussed.

\section{E-quality}

The perceived quality of Internet banking is part of the theoretical field of digital quality. It has been designed differently and has been extensively tested at commercial sites. According to Zeithaml and al. (2000), e-quality includes pre and post-service experience with the website. It 
represents "the evaluation of the effectiveness and efficiency by which a website facilitates shopping, purchase and delivery products or services. Several studies have identified dimensions of electronic quality, refering mainly to work on electronic service quality and online satisfaction (Wolfinbarger and Gilly, 2003, Srinivasan and al., 2002, Yoo and Donthu, 2001; Novak and al., 2000, Liu and Arnett, 2000; Szymanski and Hise, 2000), to work on technologies of self-service (Bateson, 1985; Dabholkar, 1996 and Meuter and al., 2000) and to work on Internet banking (Jun and Cai, 2001; Aladwani, 2001; Liao and Cheung, 2002; Jayawardhena, 2004). These studies provide information on the dimensions most frequently cited in the literature and which may serve as a basis for assessing the perceived quality of Internet banking.

\section{E-satisfaction}

Satisfaction is defined as "a psychological form resulting from an evaluation process emotional and cognitive" (Oliver 1981). The satisfaction has an indirect effect on customer intent with the position after the purchase. Fornell and al. (1996) show that cumulative satisfaction is a major antecedent of loyalty, represented by the intention to repeat purchase and tolerance of a price increase. Regarding the esatisfaction, Wolfinbarger and Gilly (2003) have identified four factors (website design, reliability, security / confidentiality and customer support) of the online shopping experience that predict strong judgement on the quality of consumer service and satisfaction with the website. Szymanski and Hise (2000) conducted a study on e-satisfaction showing that convenience, website design and security of financial transactions were the dominant factors in assessing the online satisfaction. Their results also show that positive perceptions of website design and security of financial transactions are two important factors for the evaluation of e-satisfaction. They measured overall satisfaction with regard to online trade in adapting two commonly used measures of satisfaction: satisfaction / dissatisfaction of consumers (Oliver, 1980, Zeithaml and al, 1996) and
(Pleased / unpleased) to the online purchase (Spreng and al., 1996).

\section{E-commitment}

Boulaire and Mathieu (2000, p.1) define the commitment toward a site as "a psychological state that the person maintains toward the site, characterizing her relationship with the site and its implications for the maintenance of it or not, corresponding to an emotional or (and) calculated commitment by the surfer to the site". The authors used two dimensions: affective commitment and calculated commitment. The emotional commitment to a site can result from experiences on the Internet and through a site and the immediate emotional gratification it brings. Two sub-dimensions characterize affective commitment: the symbolic dimension and the hedonistic dimension of the site. The calculated commitment refers to the cognitive process followed by the Internet to reach the outcome, the decision to continue his relationship with a site. In this perspective, the calculated commitment is characterized by three sub-dimensions: the absence of alternatives, satisfaction with the chosen site and then switching costs.

The authors therefore insist on two forms of commitment: a commitment based on emotional attachment that develops in the relationship between the Internet and the website and expressing the emotions felt during the browsing experience. The emotional dimension can have a good chance for cyberconsumer who issue with the same behavior (buying, revisiting the website) and is a more important dimension which is calculated depending on the number of alternatives or switching costs.

Park and Kim (2003) and Chiou (2004) note that on the Internet, the commitment is often seen as the intention to revisit the website, the intention to buy from the website or the intention to recommend website. In this research, commitment to the website will be considered as resulting from an overall assessment of satisfaction. It is defined as "intention to maintain a 
valued relationship with the website" (Park and Kim, 2003).

\section{The Influence of the Electronic Quality on Satisfaction}

About the virtual environment, the researches that have addressed this relationship are scarce. They can even be inventoried in four studies: Wolfinbarger and Gilly (2003), Rolland (2003), Bressolles (2004) and Rodgers and al. (2005). Rolland (2003) studied the relationship between the perceived quality of a website (Fnac.com) and satisfaction related to the website. Her results show that the perceived quality of the website positively influences satisfaction (for the model of the website information, the regression coefficient is $0,792, p=0.000$ and for the model of website procurement, it is $0,808, p=0.000$ ). This relationship has been proven by Wolfinbarger and Gilly (2003) who showed that the overall quality of service strongly predicts satisfaction of Internet users $\left(\mathrm{R}^{2}=0.70, \mathrm{p}=0.001\right)$. The same result was also confirmed by Bressolles (2004) who studied this relationship in the context of a shopping experience at two websites: a website of digital products (Nomatica) and a website tour (New Frontiers). His results show a strong positive link between the two concepts $\gamma=0,927$ for the global model and for the two websites studied: $\gamma=0,855$ for New Frontiers and $\gamma=0,953$ for Nomatica). It follows that service quality positively influences satisfaction after a purchase from a merchant website. Testing this relationship on a sample of students ( $\mathrm{N}$ = 836), Rodgers and al. (2005) showed that the perceived quality exerted a positive influence on online satisfaction $(\gamma=0.20$, p $<0.05)$. This relationship is stronger when respondents have a greater online experience $(\gamma=0.36, \mathrm{p}<0.01)$. On the contrary, if an online experience is weak, this relationship is negative $(\gamma=-0.47)$, which means that it is less likely to satisfy even less experienced consumers by providing a good quality service.

Wang (2003, p.2) notes that traditionally, the level of satisfaction is determined, among other things, by the quality of service. Therefore, the level of esatisfaction is also determined by the quality of e-services. As part of this research, perceived quality of Internet banking is defined as "the degree to which the banking site makes managing banking effectively and efficiently" (adapted from Zeithaml and al. 2000). As for satisfaction, it will be conceptualized as an overall assessment of the consumer experience. We consider the concepts of "perceived quality and satisfaction" in a relational perspective, that is to say, as assessments resulting from an aggregate of experiences (Aurier and Evrard, 1998). We also recognize that the perceived quality is an antecedent of satisfaction in the physical environment. If this result is supported by an extensive literature in this context, few studies have been addressed in the virtual domain where we are. Our goal is to test this relationship in the context of Internet banking. For this, we hypothesize:

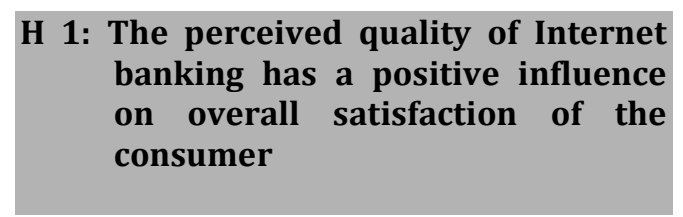

\section{The Influence of Satisfaction on Commitment}

Satisfaction as a predictor of commitment is a result well defended in several studies. Chiou (2004), examining the antecedents of commitment to an Internet access provider, showed that overall satisfaction of consumers toward a provider of Internet access positively influences their commitment to the respect of the supplier $(\gamma=0.37, t=2.84, p<0.05)$. Satisfied consumers are more likely to resort to the same website in the future, to resist in the face of competing alternatives and generate positive word of mouth. Also, Allagui and Temessek (2004) showed that the more customers are satisfied with their experience with a provider of e-services, the more committed they will be to it and the more their intentions to return and repurchase will be. The results from the structural modeling confirm a direct and positive impact of e-satisfaction on commitment $(\gamma=0.89, \mathrm{t}=12.97)$. The 
authors conclude that satisfaction with a site (portal site Yahoo) is an important antecedent of commitment. Park and Kim (2003), examining the influence of satisfaction with available information on the website and the profits on relational commitment to the website, show that satisfaction explains a strong commitment to the respect of the website $(\beta=0,448 \mathrm{t}=$ $12,469, \mathrm{p}<0.001)$. The authors emphasize the important role of satisfaction in the formation of consumer commitment in the context of buying books online. Bansal and al. (2004) studied the antecedents and consequences of online satisfaction from customers of 145 companies primarily "multi-channel distribution of products / services online, their results show the existence of a significant and positive relationship between e-overall satisfaction and intention to re-purchase $\left(\mathrm{R}^{2}=0.38, \beta\right.$ $=0.61, t=6.78)$. Anderson and Srinivasan (2003) also showed a sample of 1211 online consumers that satisfaction has a positive and significant impact on intention (behavioral intention) $(\beta=0.28, t=5143)$. Given this research, overall satisfaction is presumed to be the natural history of commitment. Therefore, it is reasonable to predict that consumers who are satisfied with the Internet banking make greater reuse. Therefore we postulate that:

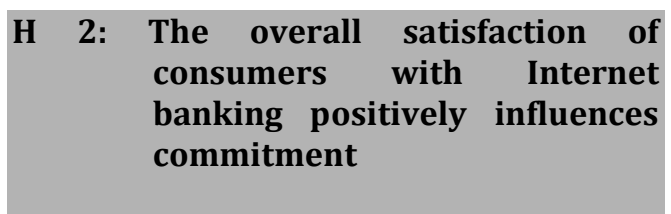

\section{The Moderating Role of Need for Personal Interaction on the Relationship: E-Quality-E-Satisfaction- Commitment}

The needs for personal interaction represent the importance of human interaction for the customer in service encounters. It measures consumer attitudes to the personal interaction (Zhu and al. 2002, p.75; Dabholkar and Bagozzi, 2002, p.188).

Zhu and al. (2002) found that consumers who need personal attention evaluate above the traditional dimensions of service quality. In addition, the need for personal attention accentuates the preference for traditional services. Cowles and Crosby (1990) suggest that the need for interpersonal contact in service delivery is very important for some customers. Those who want personal attention and social interaction are not conducive to automated services (Peterson and al. 1997) and some may eventually change companies if they lose the human interaction with their provider (Gerson, 1998). Some people perceive that the use of high technology in the service encounter dehumanizes interaction. They say nice to interact with tellers (Zeithaml and Gilly, 1987). Lidengham (1984) showed that the loss of social interaction in situations of selfservice cannot be compensated by the gain of time. For Sabadie and Vernette (2003), electronic banking may not create or destroy value over a relationship at the counter, including an incident (bank card swallowed, transfer error, and dispute the amounts ...). Conversely, contact with a turnkey reduces this risk and helps solve real-time incidents. According to Dabholkar and Bagozzi (2002), if the consumer has a great need for interaction with staff; it will eliminate self-service technology, whereas if the need is low, he will seek this kind of technology.

They add that for the consumer who has a great need for personal interaction using the delivery options for self service, they must be easy to use, reliable and pleasant.

The authors conclude that to get consumers whose need for interaction with the employee service is high and who evaluate the self-service technologies positively, all attributes of these technologies must be strong.

Bloemer and al. (2003), examining the impact of the need for social contact on satisfaction and commitment in services (hairdressing service), showed that the positive need for social contact affects satisfaction $(\beta=0.53, t=4.46)$. They found that when the consumer expresses high need for social interaction, the level of satisfaction is also high. The same effect on the commitment was predicted by authors, 
but their results show an inverse relationship between the need for social interaction and commitment $(\beta=-0.59, \mathrm{t}=-$ 2.70). We therefore propose to test the moderating role of need for personal interaction in the relationship between the perceived quality of Internet banking and e-satisfaction and the relationship between e-satisfaction and commitment.

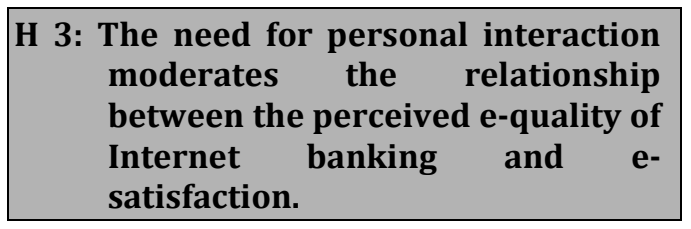

H 4: The need for personal interaction
moderates the relationship
between e-satisfaction and
customer commitment

\section{Research Methodology}

Data collection was conducted using an online questionnaire. A convenience sample of 639 users of Internet banking has been established. It comprises $42.4 \%$ men and $57.6 \%$ women. $29.8 \%$ have license as level of training and $49.8 \%$ a postgraduate or doctorate level. In addition, $92.2 \%$ of respondents use the site from their banks to manage their accounts for 2 years (balance inquiries, transfers online, credits simulations, research information ....). More than half (57.7\%) respondents use the websites of their banks several times a week to manage their banking activities.

\section{Selection and Validation of Measurement Scales}

The scale developed by Hamadi (2008) was used to measure the perceived quality of Internet banking. This scale is composed of 21 items measuring seven dimensions related to perceived quality of Internet banking. To measure satisfaction, we chose to evaluate the satisfaction as a cumulative overall assessment from a set of experiments. For that, the scale of Rolland (2003) was chosen. To measure the commitment toward a website, a unidimensional scale developed by Park and Kim (2003) was chosen. The measurement of the variable need for personal interaction comes from a scale that was developed by Dabholkar (1996) and re-tested and validated by Dabholkar and Bagozzi (2002). It is therefore retained and adapted to our research because it was developed using a rigorous methodology (factor analysis over exploratory and confirmatory, test reliability and validity) and it shows satisfactory statistical qualities including a Cronbach alpha of 0.83 .

The validity of measures of variables: electronic quality, satisfaction commitment and need of personal interaction, was verified. The psychometric qualities of these scales have been verified through an exploratory factor analysis supported by a confirmatory factor analysis $(n=629)$. The scale of the perceived quality retains its multidimensional structure. The satisfaction scale hasn't been validated, so a single-item scale of satisfaction was chosen for further analysis. The scale of the commitment has been validated and composed of items. The scale of the need for personal interaction, finally selected for further analysis, is composed of three items.

\section{Results and Discussions}

Before testing hypotheses, the test of conceptual model was performed to verify the quality of its fit to empirical data. The various fit indices show that the model is acceptable and has good fit to empirical data for the parameter estimates. The $\chi^{2}$ adjusted degree of freedom is equal to 5 , 07 , the CFI, NFI and NNFI are respectively 0,$932 ; 0,917$ and 0,909 . The RMSEA is equal to 0,081 with an interval of $(0,070$; $0,092)$, the AIC is equal to 125,94 much lower than the independent model (2409.17). So the model fit is satisfactory and interpretation of different assumptions can be made. Estimating the parameters of the structural model show the existence of a positive and significant relationship between perceived e-quality and esatisfaction $(\gamma=0,769$ and $\mathrm{T}=14,417)$. This relationship is well demonstrated in the traditional literature, but its replication 
in the context of Internet banking is a highly original contribution of this research. Thus, the e-quality perceived by users of Internet banking positively affects their e-satisfaction. The hypothesis $\mathrm{H} 1$ is confirmed. The regression coefficient of esatisfaction on commitment is positive and significant $(\gamma=0,225$ and $\mathrm{T}=2,415)$. Thus, the user satisfaction positively influences its commitment toward the Internet banking. The hypothesis $\mathrm{H} 2$ is validated.

Regarding the test of the moderating effect of need for personal interaction is the multi-group analysis in structural equation that has been done. Two sub-samples were formed: sample of individuals whose need for personal interaction is high $(\mathrm{n}=324)$ and sample of individuals whose need for personal interaction is low $(n=315)$. The results indicate that the need of personal interaction does not have a moderating influence on the relationship between perceived e-quality and e-satisfaction $\left(\mathrm{d} \chi^{2}\right.$ $=0.041, \mathrm{p}=0.84$ ) Therefore, the hypothesis $\mathrm{H} 3$ is not validated. Also, the moderating role of need for interaction in the relationship between e-satisfaction and commitment toward Internet banking is not established $\left(\mathrm{d} \chi^{2}=0,223, \mathrm{p}=0.89\right.$ ), therefore, the hypothesis $\mathrm{H} 4$ is not validated. We present in Figure 1, the relations of the model tested:

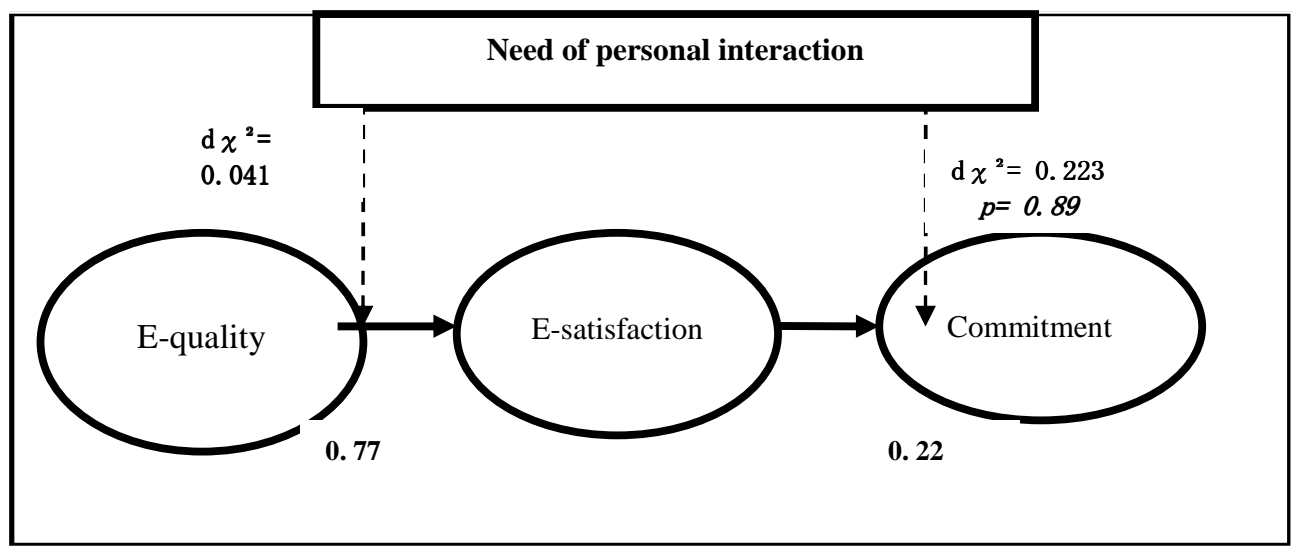

The research results show a positive and significant link between the electronic quality and satisfaction. Satisfaction is largely determined by the perceived quality as evidenced by its regression coefficient $(\gamma=0.77)$. The influence of the electronic quality on satisfaction was confirmed very strongly but the validation of this relationship is not a surprise because several researches developed in the environment of traditional services (Cronin and Taylor, 1992; Spreng and Mackoy, 1996; Sabadie, 2001; Champitaz and Swaen, 2004) and on the Internet (Wang, 2003; Wolfinbarger and Gilly, 2003; Rolland, 2003; Bressolles, 2004 and Rodgers and al. 2005; Hamadi, 2007) have all shown that. Our contribution is therefore the validation of this relationship in the context of Internet banking with a coefficient of $\gamma=0.77$. In our context, the perceived e-quality can strongly predict the satisfaction of Internet users of the Internet banking.

Moreover, our results showed a significant positive influence of e-satisfaction on commitment $(\gamma=0,22 ; t=2,415, p<0.05)$. Consumer satisfied with Internet banking engages to make greater reuse of Internet banking in the future and visits their bank first if they need banking services. These results are consistent with what Park and Kim (2003), Bansal and al. (2004) and Chiou (2004) have shown that satisfied customers are more prone to resort to the same website in the future and resist the face of competing alternatives. The more consumers are satisfied with their experiences with electronic services, the more they are committed to them and the more their intentions to return and 
repurchase will be. Furthermore, validation of this hypothesis means that the consumer undertakes toward a website or an online service should be especially pleased by it.

The lack of moderating effect in the relationship between the electronic quality, satisfaction and commitment could come from the nature of our sample which is composed in its majority from young people $(93.8 \%$ of the sample is aged 18 to 34 years) for which personal interaction is not a priority. Young people appreciate performing their transactions privately without having to talk to anyone (Nantel, 2004). Moreover, eliminating the personal interaction is one of the motivations that drive them to use Internet banking. The services required by this category of customers (consulting sales, transfers, account opening ...) do not require interpersonal interaction. It seems that these people regard the Internet banking as a complementary channel to existing banking channels. Therefore, their use of this media is not a depersonalization of their relationship with their banker. The Internet banking is a new channel that facilitates the relationship without making it totally impersonal.

\section{Research Contributions}

From a theoretical viewpoint, this research continues the few work that was interested in perceiving quality of online services on one hand. On the other hand, it enriches the theoretical framework of Internet banking. Another theoretical contribution of this research is to have studied the influence of perceived quality on satisfaction and the influence of satisfaction on the commitment toward Internet banking. The moderating role of need for personal interaction in the electronic quality and satisfaction relationship as well as the relationship between satisfaction and commitment was examined. On the managerial level, the results of this research show that satisfaction with Internet banking contributes to the commitment of customers to use Internet Banking, visit the banking website in the first place and to maintain their relationship with their bank's website.

\section{Limits and Future Research}

This research has limitations inherent conceptual and methodological choices. These limits may be good lines of future research. The first limitation concerns the sample selection of the quantitative study "students." While students are a more homogeneous sample and represent a better target for our subject, they are still individual consumers, not more because they face tighter budgetary constraints. Moreover, it was possible to introduce into the model of other moderators such as familiarity Cyber shoppers, his expertise with the site or its demographics. Also, other studies have shown the importance of other factors that may moderate the impact of designing a website on the trial of the Internet, such as attitudes toward technology (Parasumaran, 2000), innovativeness (Limayem and Frini, 2002), the propensity for variety seeking (Donthu and Garcia, 1999) and user equipment (Galan, 2000).A critical limit is certainly not taking a sample that takes into account other occupational categories. A larger sample would have to make a greater representation of consumer users of Internet Banking and therefore more external validity to our research

\section{References}

Aladwani, A. M. (2001). “Online Banking: A Field Study of Driver,Development Challenges, and Expectations," International Journal of Information Management. 21; pp. 213-225.

Allagui, A. \& Temessek, A. (2004). "La Fidélité des Utilisateurs des Services d'un Portail Internet: Proposition et Test d'un Modèle Intégrateur," C.R.G.N.A, IAE de Nantes.

Aurier, P. \& Evrard, Y. (1998). 'Elaboration et Validation d'une échelle de Mesure de la Satisfaction des Consommateurs,' Actes du 14èmeCongrès International de l'AFM Bordeaux.

Bansal, H. S., McDougall, G., Dikolli, S. S. \& Sedatole, K. L. (2004). "Relating ESatisfaction to Behavioral Outcomes: An 
Empirical Study," Journal of Services Marketing vol.18, 4.

Bateson, J. E. G. (1985). 'Self-Service Consumer: An Exploratory Study, 'Journal of Retailing, 61, 3, pp. 49- 76.

Boulaire, C. \& Mathieu, A. (2000). 'La Fidélité à un Site Web: Proposition d'un Cadre Conceptuel Préliminaire,' Actes du 16ème Congrès International de l'AFM, Montréal.

Bressolles, G. (2004). 'La Qualité de Service électronique, NETQUAL: Mesure, Conséquences et Variables Modératrices,' Thèse de doctorat en sciences de gestion, Université de Toulouse I.

Champitaz, R. \& Swaen, V. (2004). "La Qualité perçue Comme Déterminant de la Satisfaction des Clients en Business-ToBusiness. Une Étude Empirique dans le Domaine de la Téléphonie," Recherche et Application en Marketing vol. 19, 2, pp. 3152.

Chiou, J. S. (2004). "The Antecedent of Consumers' Loyalty toward Internet Service Providers," Information \& Management (2004), vol. 41, pp. 685-695.

Churchill, G. A. (1979). “A Paradigm for Developing Better Measures of Marketing Constructs," Journal of Marketing Research, Février , 16, 64-73.

Cowles, D. \& Crosby, L. A. (1990). "Consumer Acceptance of Interactive Media," The Service Industry Journal, vol. $10, n^{\circ} 3$, pp. 521-540.

Cronin, J. J. Jr. \& Taylor, S. A. (1992). "Measuring Service Quality: A Reexamination And Extension," Journal of Marketing, 56; 56-68.

Dabholkar, P. \& Bagozzi, R. P. (2002). “An Attitudinal Model of Technology-Based Self-Service: Moderating Effect of Consumer Traits and Situational Factors," Journal of the Academy of Marketing Science, vol. 30, 3, pp. 184-201.
Donthu, N. \& Garcia, A. (1999). "The Internet Shopper," Journal of Advertising Research, vol, 39, 3, 52-58.

Galan, J. Ph. (2000). 'The potential impact of music on the Web user behavior: framework, research avenues and obstacles,' The 6th international Seminar in service Management, La londe les Maures, 277-299.

HAMADI C. (2007). 'The Perceived Quality of Internet Banking and its Influence on Satisfaction and Customer Commitment,' PhD in Management Science, University of Toulouse

1.

HAMADI, C. (2008). 'La Qualité Perçue de l'Internet Bancaire: Proposition d'une échelle de Mesure,' Actes du 1er Colloque International sur le management de la confiance et Internet ,27 Juin, Aix-en Provence, France.

Jayawardhena, C. (2004). "Measurement of Service Quality in Internet banking: The Development of an Instrument," Journal of Marketing Management, vol. 20, 185-207.

Jun, M. \& Cai, S. (2001). "The Key Determinants of Internet Bancaire Service Quality: Content Analysis," The International Journal of Bank Marketing, vol.19, 7.

Ledingham, J. A. (1984). 'Are Consumers Ready for the Information Age?,' Journal of Advertising Research, vol. 24, 4, 31-37.

Liao, Z. \& Cheung, M. T. (2002). "Internet Based E-Banking and Consumer Attitudes: An Empirical Study," Information and Management, vol. 39, pp. 283-295.

Limayem, M.\& et Frini, A. (2000). 'Les Facteurs Influençant les Intentions d'achat à Partir du Web: Comparaison Entre Acheteurs et Non Acheteurs,' http://www.aim2000.univmontp2.fr/ aim 2000/pdf/Frini.pdf.

Liu, C. \& Arnett ,K. P. (2000). “Exploring the Factors Associated with Web Site Success in the Context of Electronic Commerce," Information \& Management, vol. 38, 1. 
Llosa, S. (1996). 'Contribution à l'étude de la Satisfaction dans les Services,' Thèse de doctorat en Sciences de Gestion, Université d'Aix Marseille III.

Meuter, M. L., Ostrom, A. L., Roundtree, R. I. \& Bitner, M. J. (2000). "Self-Service Technologies: Understanding Customer Satisfaction with Technology-Based Service Encounters," Journal of Marketing, 64, 3, 50-64.

Nantel, J., Pratte, M. C., Renaud, J. F. \& Leblanc, M. (2004). 'Online Banking Services in Canada,' Working paper In Partnership with Adviso Conseil, HEC, Montréal, Février.

Novak, T. P., Hoffman, D. L. \& Yung, Y. F. (2000). "Measuring the Customer Experience in Online Environments: A Structural Modeling Approach," Marketing Science, vol. 19,1.

Parasuraman, A. (2000). "Technology Readiness Index (TRI): A Multiple Item Scale to Measure Readiness to Embrace New Technologies," Journal of Services Research, 2, 4, 307-320.

Park, C. H. \& Kim, Y. G. (2003). "Identifying Key Factors Affecting Consumer Purchase Behavior in an Online Shopping Context," International Journal of Retail \& Distribution Managemet vol. 31, 1, pp. 1629.

Peterson, R. A., Balasubramanian, S. \& Bronnenberg, B. J. (1997). "Exploring the Implications of Internet for Consumer Marketing," Journal of the Academy of Marketing Science, 25, 4, 329-346.

Rolland, S. (2003). 'L'impact de l'utilisation d'Internet sur la Qualité Perçue et la Satisfaction du Consommateur,' Thèse de Doctorat en Sciences de Gestion, Université Paris Dauphine.

Roussel, P., Durrieu, F., Campoy, E. \& El Akremi, A. (2002). "Méthodes d'équations Structurelles: Recherche et Applications en Gestion," Éd. Economica.
Sabadie, W. \& Vernette, E. (2003). "La Servuction «On Line » Points Communs et Spécificités Face à la Servuction Traditionnelle," Actes des journées nantaises de recherche sur le E-marketing, Nantes.

Sabadie W. (2001). 'Contribution à la mesure de la qualité perçue d'un service public,' Thèse de Doctorat en Sciences de Gestion, Université de Toulouse 1.

Srinivasan, S. S., Anderson, R. \& Ponnavolu, K. (2002). "Customer Loyalty in ECommerce: an Exploration of Its Antecedents and Consequences," Journal of Retailing, 78, pp.41-50.

Szymanski, D. M. \& Hise, R. T. (2000). "ESatisfaction: An Initial Examination," Journal of Retailing, 76 (3), 309.

Wang, M. (2003). 'Assessment of E-Service Quality via E-Satisfaction in E-Commerce Globalisation,' The Electronic Journal of Information Systems in Developing Countries,11,10, p.1-4.

Wolfinbarger, M. \& Gilly, M. C. (2003). "ETailq: Dimensionalizing, Measuring and Predicting Etail Quality," Journal of Retailing, 79, 183-198.

Yoo, B. \& Donthu, N. (2001). 'Developing a Scale to Measure the Perceived Quality of Internet Shopping Sites,' Quarterly Journal of Electronic Commerce, 2,1, 31-47.

Zeithaml, V. A. \& Gilly, M. C. (1987). 'Characteristics Affecting the Acceptance of Retailing Technologies: A Comparison of Elderly and Nonelderly Consumer,' Journal of Retailing, vol. 6, 31, pp. 49-68.

Zeithaml, V. A., Parasuraman, A. \& Malhotra, A. (2000). 'E-service Quality: Definition, Dimensions and Conceptual Model,' Working paper, Marketing Science Institute, Cambridge, MA. 
Appendix:

Table 1: Internet Banking Perceived Quality Scale

\begin{tabular}{|c|c|}
\hline Code & Items \\
\hline & WEB SITE DESIGN \\
\hline DESIGN1 & The site of my bank is visually pleasing \\
\hline DESIGN2 & The site of my bank is visually attractive \\
\hline \multirow[t]{2}{*}{ DESIGN5 } & The colour of the site of my bank are well prepared \\
\hline & EASE OF USE \\
\hline FACUT1 & It is easy for me to learn how to use the site of my bank \\
\hline FACUT5 & I found my bank site easy to use \\
\hline FACUT3 & It is easy to remember how to use the site of my bank \\
\hline \multirow[t]{2}{*}{ FACUT7 } & It is easy to navigate around the site of my bank \\
\hline & $\underline{\text { PRIVACY }}$ \\
\hline PRIVACY 5 & The site of my bank protects banking secret \\
\hline PRIVACY 1 & I think my privacy is protected on this site \\
\hline PRIVACY 2 & $\begin{array}{l}\text { I am confident that the site of my bank is not using my personal information } \\
\text { inappropriately }\end{array}$ \\
\hline \multirow[t]{2}{*}{ SECU2 } & I have confidence in the safety of my bank site \\
\hline & INFORMATION QUALITY \\
\hline INFQ1 & The site of my bank meets my needs for information \\
\hline INFQ3 & Information on the site of my bank is relevant \\
\hline \multirow[t]{2}{*}{ INFQ2 } & The information corresponds to what I need \\
\hline & $\underline{\text { SECURITY }}$ \\
\hline SECU6 & My bank communicates its security policies on its website \\
\hline \multirow[t]{2}{*}{ SECU5 } & On the site of my bank, there are clear explanations of security \\
\hline & TIME SAVING \\
\hline TIMESAV2 & It's fast to do transactions on the site of my bank \\
\hline TIMESAV3 & I earn a lot of time using the site of my bank \\
\hline \multirow[t]{2}{*}{ TIMESAV1 } & The site of my bank does not make me lose my time \\
\hline & INTERACTIVITY \\
\hline INTER7 & The site provides a means for contacting my bank advisor \\
\hline INTER4 & $\begin{array}{l}\text { I can communicate with a person from my bank (by e-mail.) When I have a } \\
\text { problem with my account }\end{array}$ \\
\hline
\end{tabular}


Table 2 : Satisfaction Scale

Finally, toward your bank web site you are:

\begin{tabular}{|c|c|c|c|c|c|c|}
\hline $\begin{array}{c}\text { Extremely } \\
\text { unsatisfied }\end{array}$ & $\begin{array}{c}\text { Very } \\
\text { unsatisfied }\end{array}$ & Unsatisfied & $\begin{array}{c}\text { Nor satisfied } \\
\text { nor insatisfait }\end{array}$ & Satisfied & $\begin{array}{c}\text { Very } \\
\text { satisfied }\end{array}$ & $\begin{array}{c}\text { Extremely } \\
\text { satisfied }\end{array}$ \\
\hline $\mathbf{1}$ & $\mathbf{2}$ & $\mathbf{3}$ & $\mathbf{4}$ & $\mathbf{5}$ & $\mathbf{6}$ & $\mathbf{7}$ \\
\hline
\end{tabular}

Table 3 : Commitment Scale

\begin{tabular}{|l|l|}
\hline Code & \multicolumn{1}{|c|}{ Items } \\
\hline COMMIT1 & I will not stop using the website of my bank in the future \\
\hline COMMIT2 & I will continue to use the services of my banking site \\
\hline COMMIT4 & I visit the site first if I need banking services \\
\hline
\end{tabular}

Table 4: Need for Personal Interaction Scale

\begin{tabular}{|c|l|}
\hline Code & \multicolumn{1}{|c|}{ Items } \\
\hline INTERAC1 & $\begin{array}{l}\text { Human contact in the delivery of services makes the process enjoyable } \\
\text { for me }\end{array}$ \\
\hline INTERAC2 & I like interacting with the person who provides services \\
\hline INTERAC4 & I get tired of using the site when I could talk to someone instead \\
\hline
\end{tabular}

